\title{
Routes to heterotrinuclear metal siloxide complexes for cooperative activation of $\mathrm{O}_{2}$
}

Marie-Louise Wind, Santina Hoof, Beatrice Cula-Braun, Christian Herwig, Christian Limberg*

1. Analytical measurements

1.1 IR measurements $\quad$ S1

$\begin{array}{lll}1.2 & \text { ESI-MS measurements } & \text { S2 }\end{array}$

$\begin{array}{lll}1.3 \mathrm{UV} / \mathrm{vis} \text { and further measurements } & \mathrm{S} 4\end{array}$

1.3.1 Stability measurements $\quad$ S5

1.3.2 Reactivity measurements $\quad$ S8

$\begin{array}{lll}\text { 1.3.3 Titration experiments } & \text { S9 }\end{array}$

$\begin{array}{lll}\text { 2. Crystal data } & \text { S8 }\end{array}$

3. Density functional calculations $\quad$ S15

4. References $\quad$ S18 


\section{Analytical measurements}

\subsection{IR measurements}

Discussion is performed together with the X-ray data in section 2 .
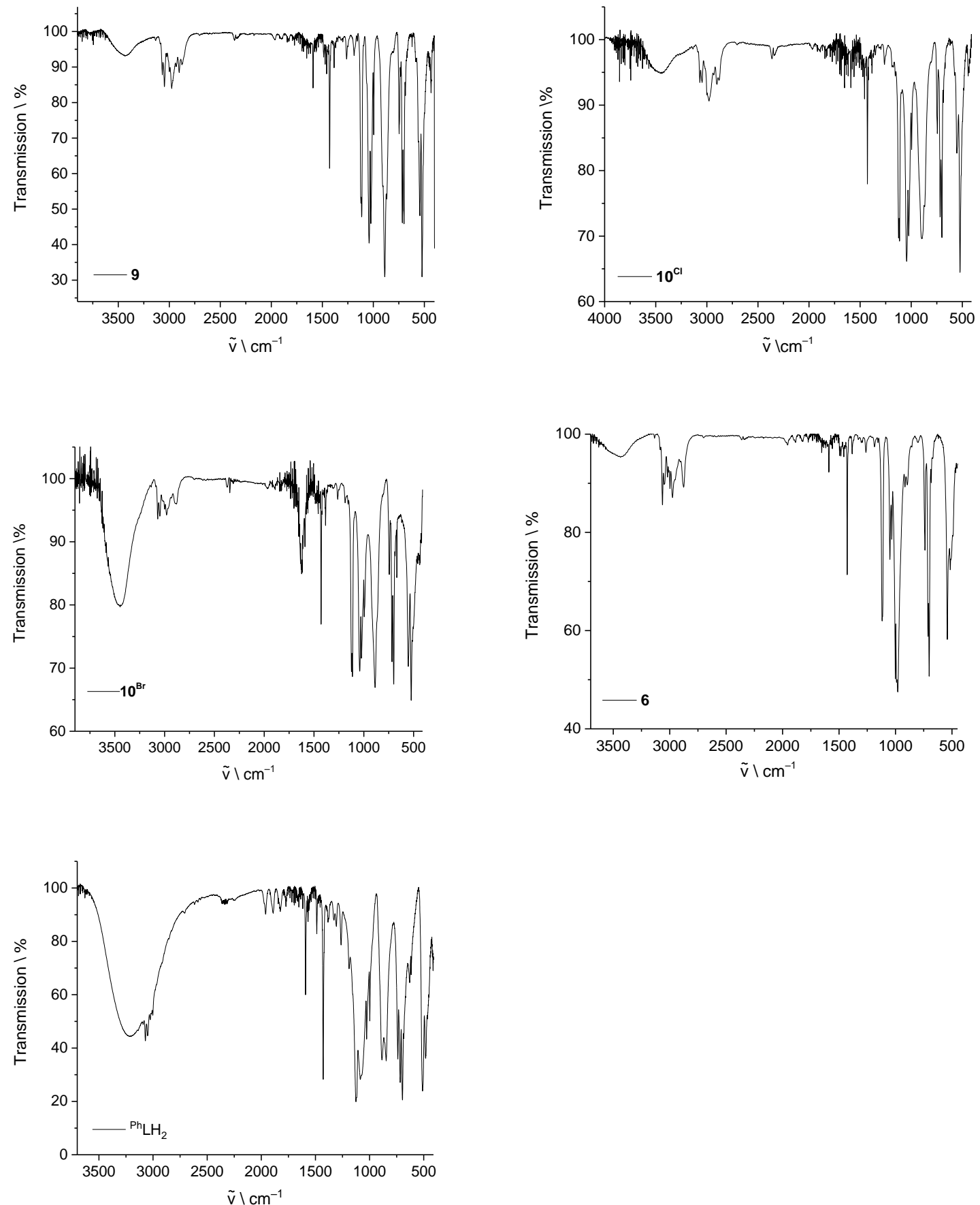

Figure S1. IR-spectra for KBr pellets of 9 (top left), $\mathbf{1 0}^{\mathrm{Cl}}$ (top right), $\mathbf{1 0}^{\mathrm{Br}}$ (middle left), $\mathbf{6}$ (middle right), ${ }^{\mathrm{Ph}} \mathrm{LH}_{2}$ (bottom left). The band at $3500 \mathrm{~cm}^{-1}$ in the spectrum of $9, \mathbf{1 0}^{\mathrm{Cl}}, \mathbf{1 0}^{\mathrm{Br}}$ and $\mathbf{6}$ is due to residual water in the $\mathrm{KBr}$. The band at $2360 \mathrm{~cm}^{-1}$ in the spectrum of $\mathbf{9}, \mathbf{1 0}^{\mathrm{Cl}}$ and $\mathbf{1 0}^{\mathrm{Br}}$ is due to residual $\mathrm{CO}_{2}$ and the band in the region $1790-1500 \mathrm{~cm}^{-1}$ is due to residual $\mathrm{H}_{2} \mathrm{O}$ in the instrument's atmosphere. 

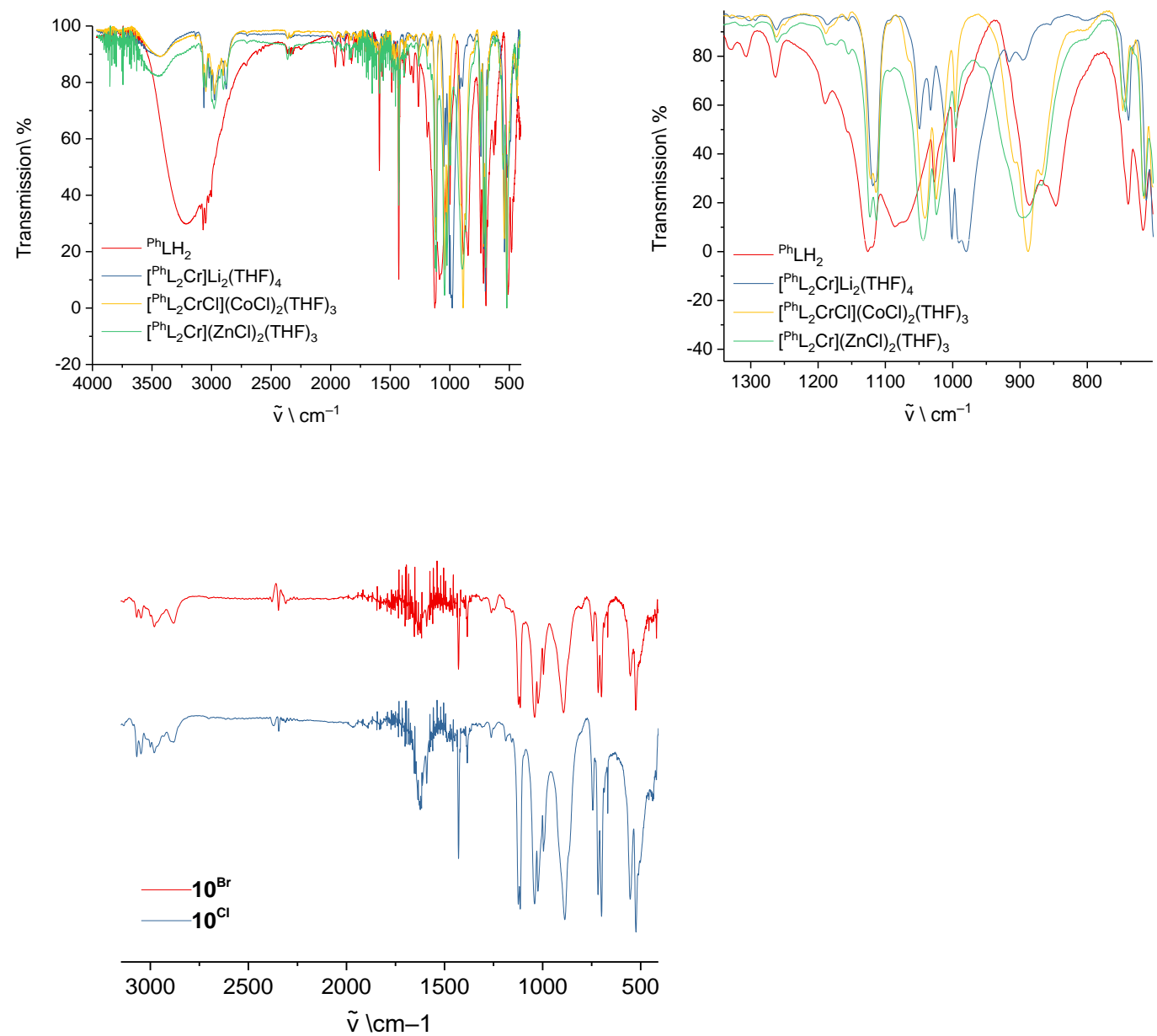

Figure S2. Comparison of the spectra of ${ }^{\mathrm{Ph}} \mathrm{LH}_{2}, \mathbf{6}, \mathbf{9}$ and $\mathbf{1 0}^{\mathrm{Cl}}$ in the region between $400-4000 \mathrm{~cm}^{-1}$ (top left). All IR spectra were normalized for this purpose. Comparison of the spectra of ${ }^{\mathrm{Ph}} \mathrm{LH}_{2}, \mathbf{6}, \mathbf{9}$ and $\mathbf{1 0}^{\mathrm{Cl}}$ in the region between $700-1300 \mathrm{~cm}^{-1}$ (top right). Direct comparison of the IR spectrum of $\mathbf{1 0}^{\mathbf{C l}}$ and $\mathbf{1 0}^{\mathrm{Br}}$ (bottom left).

\section{$1.2 \quad$ ESI-MS measurements}

ESI-MS measurements of complex 9 dissolved in MeCN showed intense ion peaks at $\mathrm{m} / \mathrm{z}=1157.9184$ and 1153.9589, which correspond to $\left.\left[{ }^{\mathrm{Ph}} \mathrm{L}_{2} \mathrm{CrCl}\right][\mathrm{CoCl}]_{2}+\mathrm{MeCN}+\mathrm{H}_{2} \mathrm{O}\right]^{-}$(calcd. $m / z=1157.9413$ ) and $\left.\left[{ }^{\mathrm{Ph}} \mathrm{L}_{2} \mathrm{CrCl}\right][\mathrm{CoCl}]_{2}+\mathrm{EtCN}\right]^{-}$(calcd. $\left.\mathrm{m} / z=1153.9401\right)$, respectively (EtCN results from the solvent used to dissolve 9, as propionitrile is a common impurity in $\mathrm{MeCN}$ [In The MAK-Collection for Occupational Health and Safety; pp 1-41].). The values and isotopic distribution patterns are in good agreement with the calculated ones. 

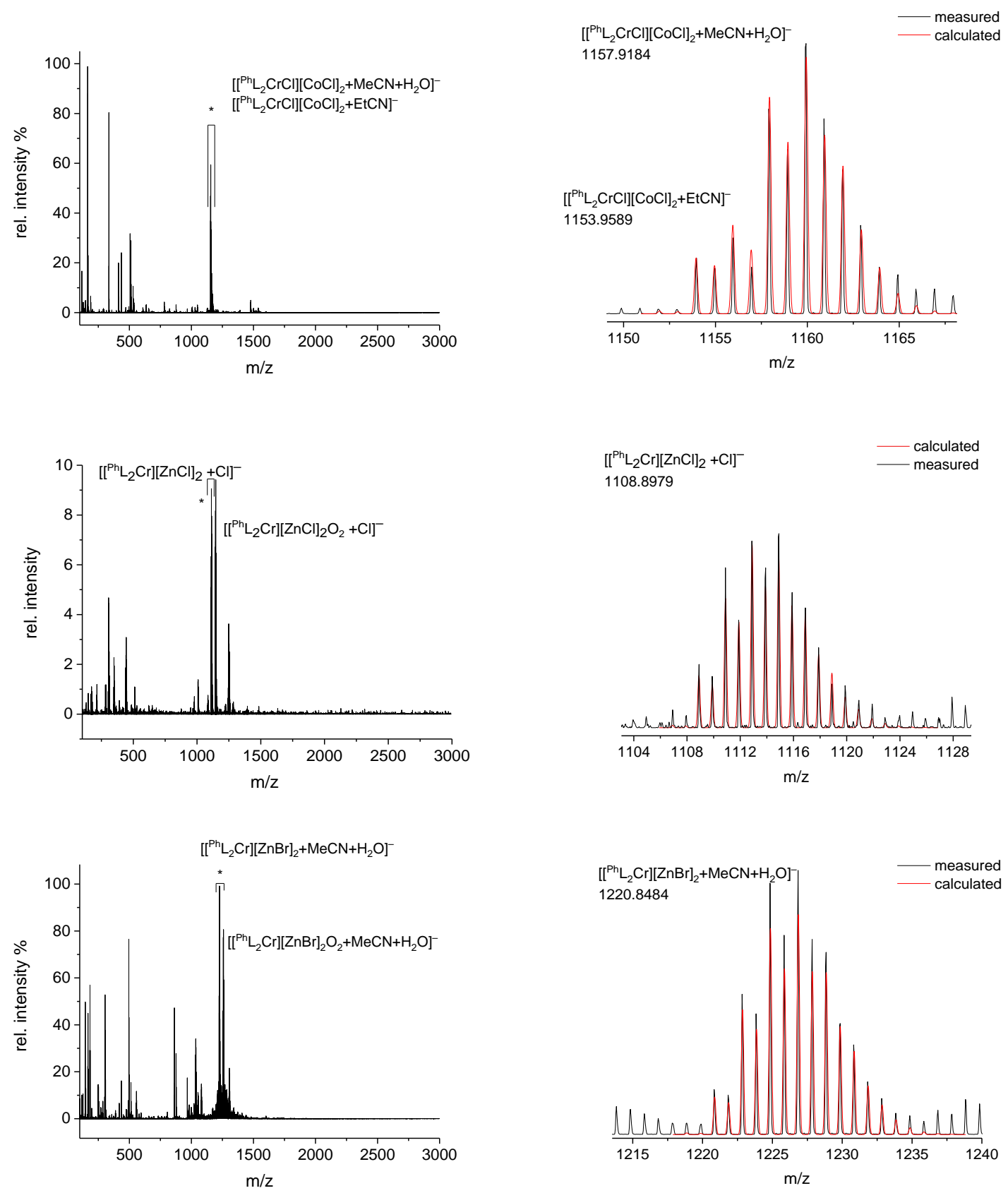

Figure S3. Top left: Full ESI-MS spectrum recorded for an acetonitrile solution of 9. Top right: Section* of the ESIMS spectrum on the left. Middle left: Full ESI-MS spectrum recorded for a THF solution of $\mathbf{1 0}^{\mathrm{Cl}}$ (direct injection). Middle right: Section * of the ESI-MS spectrum on the left. Bottom left: Full ESI-MS spectrum recorded for a $\mathrm{MeCN}$ solution of $\mathbf{1 0}^{\mathbf{B r}}$ (direct injection). Bottom right: Section * of the ESI-MS spectrum on the left. In case of $\mathbf{1 0}^{\mathrm{Cl}}$ and $\mathbf{1 0}^{\mathrm{Br}}$ additionally peaks are observed that belong to oxygenated ions, formed during the measurement in the spectrometer. When solutions were not injected directly, complete conversion to the oxygenated species was observed.

Subsequent to the reactions of $\mathbf{1 0}^{\mathbf{C} / \mathbf{B r}}$ with $\mathrm{O}_{2}$ intense signals at $\mathrm{m} / \mathrm{z}=1177.9383$ and 1191.9539 were observed, which correspond to $\left[\left[^{\mathrm{Ph}} \mathrm{L}_{2} \mathrm{Cr}\right][\mathrm{ZnCl}]_{2} \mathrm{O}_{2}+\mathrm{THF}\right]^{-}$(calcd. $\mathrm{m} / z=1177.9746$ ) and $\left.\left[{ }^{\mathrm{Ph}} \mathrm{L}_{2} \mathrm{Cr}\right][\mathrm{ZnCl}]_{2} \mathrm{O}_{2}+\mathrm{C}_{4} \mathrm{H}_{6} \mathrm{O}_{2}\right]^{-}(\mathrm{m} / z=1191.9539)$, respectively. As $\gamma$-butyrolactone can occur as one of the products in the oxidation reaction of THF (Mallat, T.; Baiker, A. Reactions in "sacrificial" solvents. 
Catalysis Science \& Technology 2011, 1 (9), 1572-1583 DOI: 10.1039/C1CY00207D.), the additional $\mathrm{C}_{4} \mathrm{H}_{6} \mathrm{O}_{2}$ mass in the latter peak likely corresponds to this molecule, which was also observed by NMR spectroscopy. In the case of $\mathbf{1 0}^{\mathrm{Br}}$ an ion peak at $\mathrm{m} / \mathrm{z}=1252.8386$, which corresponds to $\left.\left[{ }^{\mathrm{Ph}} \mathrm{L}_{2} \mathrm{Cr}\right][\mathrm{ZnBr}]_{2} \mathrm{O}_{2}+\mathrm{MeCN}+\mathrm{H}_{2} \mathrm{O}\right]^{-}$(calcd. $m / z=1252.8532$ ), was observed (Figure S4). The isotopic distribution patterns are in both cases in good agreement with the calculated values.
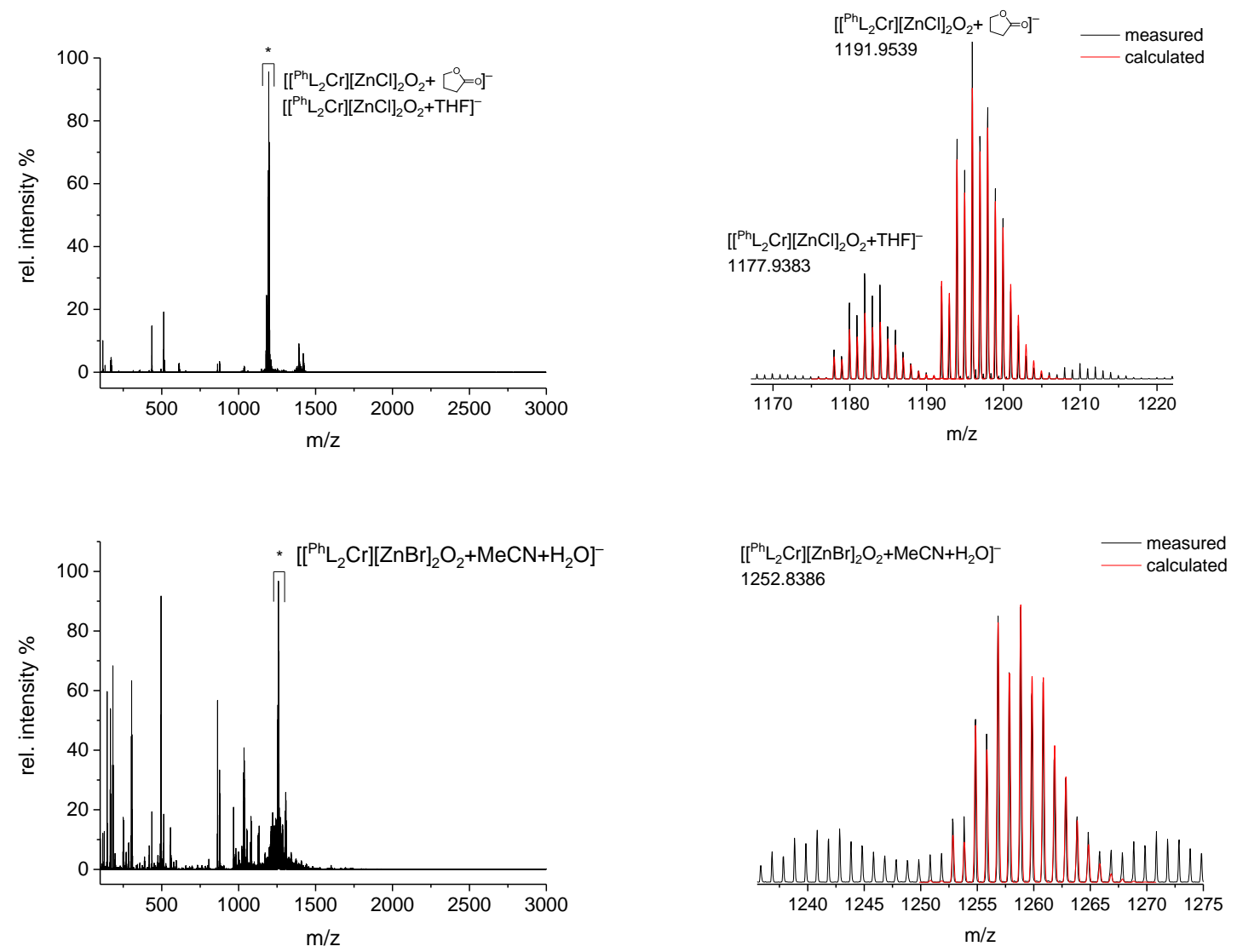

Figure S4. Top left: Full ESI-MS spectrum recorded for a THF solution of $\mathbf{1 1}^{\mathbf{C l}}$ (direct injection). Top right: Section * of the ESI-MS spectrum on the left. Bottom left: Full ESI-MS spectrum recorded for a MeCN solution of $\mathbf{1 1}^{\mathrm{Br}}$ (direct injection). Bottom right: Section * of the ESI-MS spectrum on the left.

\subsection{UV/Vis and further experiments}

Prior to all measurements the pure solvent was cooled to the required temperature in a cuvette $(\varnothing 1 \mathrm{~cm}$, $2 \mathrm{~mL})$; subsequently, the respective starting compounds $\left[{ }^{\mathrm{Ph}} \mathrm{L}_{2} \mathrm{Cr}\right][\mathrm{ZnX}]_{2}(\mathrm{Sol})_{3}(\mathrm{X}=\mathrm{Cl}, \mathrm{Br}, \mathrm{Sol}=\mathrm{THF})$ $\left(\mathbf{1 0}^{\mathrm{C} / \mathrm{Br}}\right)$ or $\left[{ }^{\mathrm{Ph}} \mathrm{L}_{2} \mathrm{Cr}\right] \mathrm{Li}_{2}(\mathrm{THF})_{4}(\mathbf{6})$ dissolved in $0.2 \mathrm{~mL}$ solvent were added. After equilibrating the temperature, the measurement was started and dioxygen was added.

To generate $\left.\left[{ }^{\mathrm{Ph}} \mathrm{L}_{2} \mathrm{Cr}\right][\mathrm{CoCl}]_{2} \mathrm{O}_{2}(\mathbf{1 2}),\left[{ }^{\mathrm{Ph}} \mathrm{L}_{2} \mathrm{Cr}\right] \mathrm{Li}_{2} \mathrm{O}_{2}(\mathrm{Sol})\right)_{4}(\mathrm{Sol}=\mathrm{THF})(\mathbf{1})$ was generated as stated above, the solution was flushed with argon for $60 \mathrm{~s}$ and 2.1 equivalents of $\mathrm{CoCl}_{2}$ were added to the solution. Likewise, $\left.{ }^{\mathrm{Ph}} \mathrm{L}_{2} \mathrm{Cr}\right][\mathrm{ZnX}]_{2} \mathrm{O}_{2}(\mathrm{Sol})_{2}(\mathrm{X}=\mathrm{Cl}, \mathrm{Br}$, Sol = THF $)\left(\mathbf{1 1}^{\mathrm{Cl} / \mathbf{B r}}\right)$ can be generated by adding $\mathrm{ZnCl}_{2}$ or $\mathrm{ZnBr}_{2}$ to a solution of $\mathbf{1}$ (spectra under section 1.3.3). 
Data points for all measurements were collected every $0.5 \mathrm{~s}$.

\subsubsection{Stability measurements}

To measure the stability of the different superoxide complexes $\left[{ }^{\mathrm{Ph}} \mathrm{L}_{2} \mathrm{Cr}\right][\mathrm{ZnX}]_{2} \mathrm{O}_{2}(\mathrm{Sol})_{2}(\mathrm{X}=\mathrm{Cl}, \mathrm{Br}$, Sol $=\mathrm{THF}, \mathrm{EtCN})\left(\mathbf{1 1}^{\mathrm{C} / \mathbf{B r}}\right.$ and $\left.* \mathbf{1 1}^{\mathrm{C} / \mathbf{B r}}\right)$ and $\left[{ }^{\mathrm{Ph}} \mathrm{L}_{2} \mathrm{Cr}\right] \mathrm{Li}_{2} \mathrm{O}_{2}(\mathrm{Sol})_{4}(\mathrm{Sol}=\mathrm{THF}, \mathrm{EtCN})(\mathbf{1}$ and $\mathbf{3})$ solutions of the starting compounds $10^{\mathrm{Cl}}, \mathbf{1 0}^{\mathrm{Br}}$ and $\mathbf{6}$ in THF or propionitrile were prepared and reacted with dioxygen as stated above (beginning of this section 1.3) and the self-decay/disappearance of the oxygen associated bands (11 ${ }^{\mathrm{C} / \mathrm{Br}} 302 \mathrm{~nm}$ (THF), *11 ${ }^{\mathrm{C} / \mathbf{B r}} 300 \mathrm{~nm}$ (EtCN), $1310 \mathrm{~nm}$ (THF), $\left.3306 \mathrm{~nm}(\mathrm{EtCN})\right)$ was monitored.

Pseudo first order rate constants were determined according to equation $\mathrm{A}=\mathrm{a}+\mathrm{b} \cdot \mathrm{e}^{-\mathrm{kt}}$ (where $\mathrm{k}$ is the rate, $\mathrm{A}$ is the absorbance of the oxygen associated bands and $\mathrm{b}$ is the absorbance at $\mathrm{t}=0$ ).

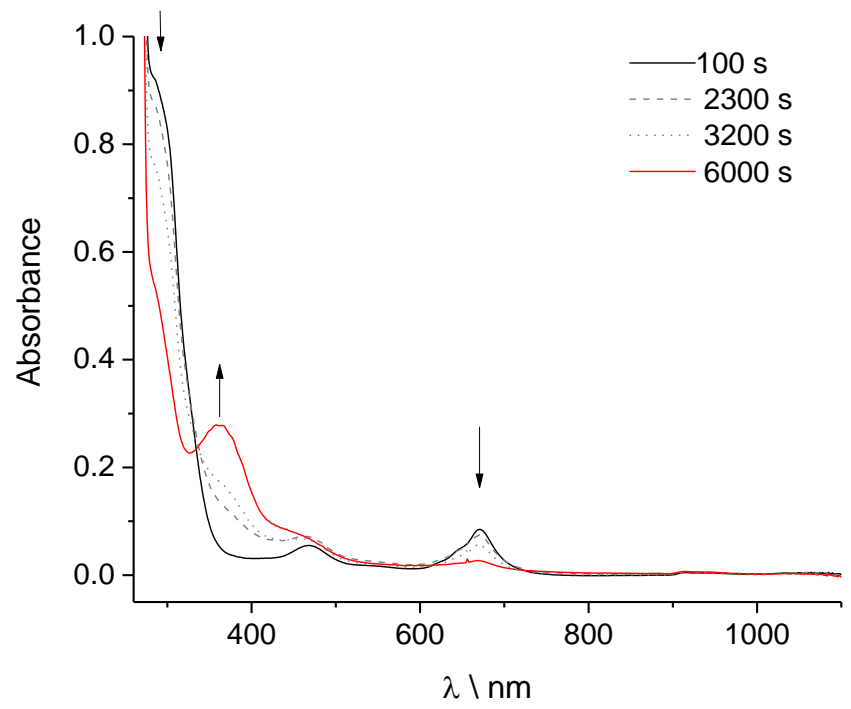

Figure S5. Decay of $* 11^{\mathrm{Cl}}$ in $\mathrm{EtCN}$ at $10{ }^{\circ} \mathrm{C}$. black: $* \mathbf{1 1}^{\mathrm{Cl}}$, red: decay product. The resulting spectrum is representative also for the decay spectrum obtained starting from $\mathbf{1 1}^{\mathrm{Cl}}$ in THF as well as the spectra observed after the decay of $11^{\mathrm{Br}}, * 11^{\mathrm{Br}}$, which in turn are identical to the ones observed for $\mathbf{1}, \mathbf{2}$ and $\mathbf{3}$ in the corresponding solvents.

To investigate the decay reaction more closely the resulting solution was analyzed by ${ }^{1} \mathrm{H}$ NMR spectroscopy and signals observed, e.g. at chemical shifts of 4.12, 2.34 and $2.13 \mathrm{ppm}$ (in deuterated acetone) are attributed to $\gamma$-butyrolactone resulting from the oxidation of THF. The sample was filtered over Chelex 400 and celite before measuring. 


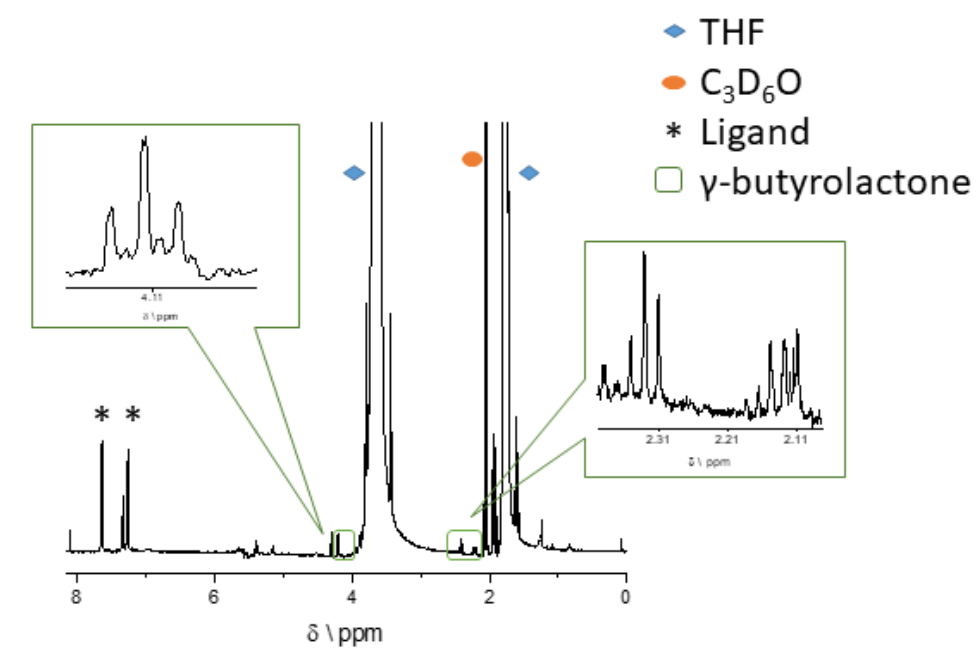

Figure S6. $\quad{ }^{1} \mathrm{H}$ NMR spectrum of the solution resulting from the decay of $\mathbf{1 1}^{\mathbf{C l}}$ in THF after $4 \mathrm{~h}$, measured at room temperature after addition of acetone

To confirm the participation of THF in the decay reaction, the reactions in deuterated and non-deuterated $\mathrm{THF}$ at $60^{\circ} \mathrm{C}$ were monitored UV/Vis spectroscopically. Rate constants of ${ }^{\mathrm{THF}} \mathrm{k}_{\mathrm{obs}}:(44.60 \pm 0.56) \times 10^{-4}$, ${ }^{d-T H F} K_{o b s}:(9.38 \pm 0.01) \times 10^{-4}$ could be determined, from which a kinetic isotopic effect of 4.75 could be derived. The existence of a positive KIE confirms the assumption that solvent is involved in the decay as substrate.
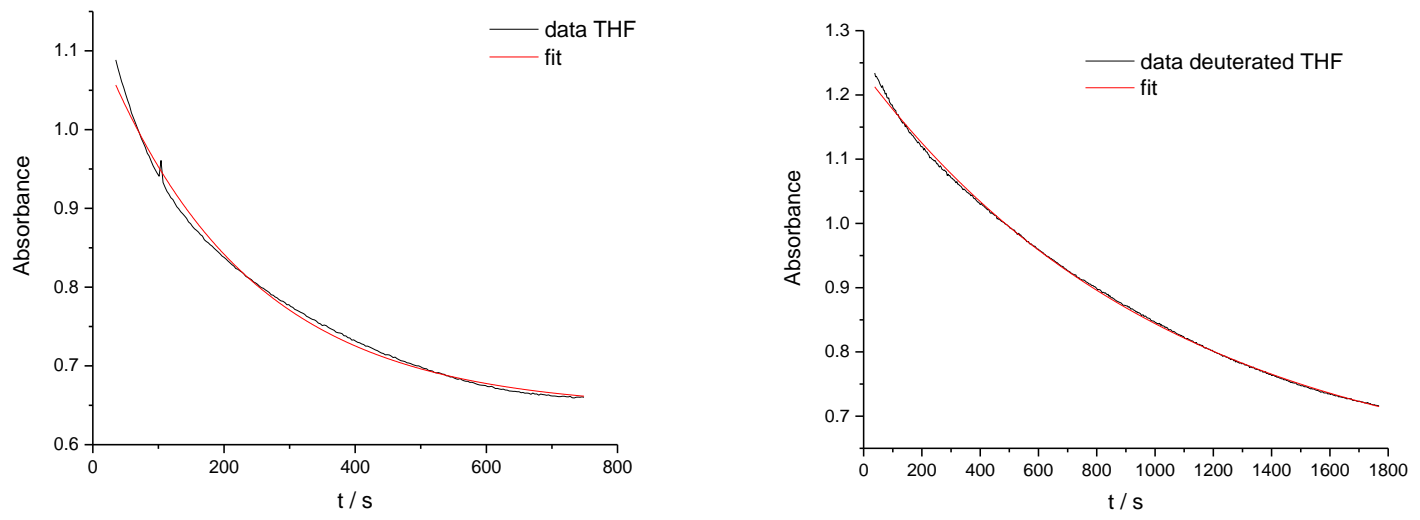

Figure S7. Time Course of the decay of $\mathbf{1 1}^{\mathrm{Cl}}$ in THF (left) and deuterated THF (right) at $60{ }^{\circ} \mathrm{C}$.

To investigate the stability of $\left[{ }^{\mathrm{Ph}} \mathrm{L}_{2} \mathrm{Cr}\right][\mathrm{CoCl}]_{2} \mathrm{O}_{2}(\mathbf{1 2}),\left[{ }^{\mathrm{Ph}} \mathrm{L}_{2} \mathrm{Cr}\right] \mathrm{Li}_{2} \mathrm{O}_{2}(\mathrm{THF})_{4}(\mathbf{1})$ was prepared as stated above (beginning of this section 1.3) in THF at $10{ }^{\circ} \mathrm{C}$. After formation of $\mathbf{1}$ the solution was flushed with argon for $60 \mathrm{~s}$ and subsequently 2 equiv. of $\mathrm{CoCl}_{2}$ dissolved in THF were added. Then the selfdecay/disappearance of the oxygen associated bands $(303 \mathrm{~nm})$ and the formation of the decay product at $350 \mathrm{~nm}$ was monitored. 


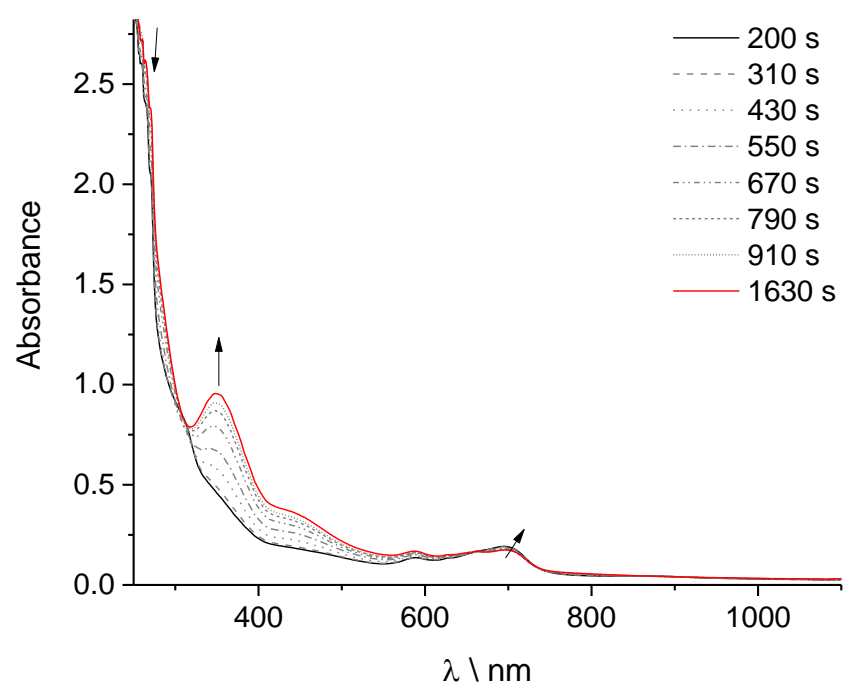

Figure S8. Decay of $\mathbf{1 2}$ in $\mathrm{THF}$ at $25^{\circ} \mathrm{C}$.

\subsubsection{Reactivity measurements}

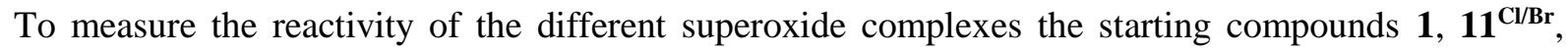
$* \mathbf{1 1}{ }^{\mathrm{C} / \mathrm{Br}}$ and $\mathbf{1 2}$ were prepared as stated above (beginning of this section 1.3) in propionitrile or THF and cooled to $-80{ }^{\circ} \mathrm{C}$. The solutions were then flushed with argon for $100 \mathrm{~s}$ before TEMPO-H was added.

Pseudo first order rate constants were determined according to equation $\mathrm{A}=\mathrm{a}+\mathrm{b} \cdot \mathrm{e}^{-\mathrm{kt}}$ (where $\mathrm{k}$ is the rate, $\mathrm{A}$ is the absorbance of the oxygen associated bands and $\mathrm{b}$ is the absorbance at $\mathrm{t}=0$ ).

The solutions obtained after the reactions were analyzed by EPR spectroscopy and in all cases an EPR spectrum like the one below was observed. All samples were quantified against a $\mathrm{Cu}$ (II) standard revealing a near quantitative conversion. To determine the g-values, spectra were simulated with Easyspin.

g-values: $\mathrm{g}_{\mathrm{xx}} 2.0108, \mathrm{~g}_{\mathrm{yy}} 2.0062, \mathrm{~g}_{\mathrm{zz}} 2.0024$ 


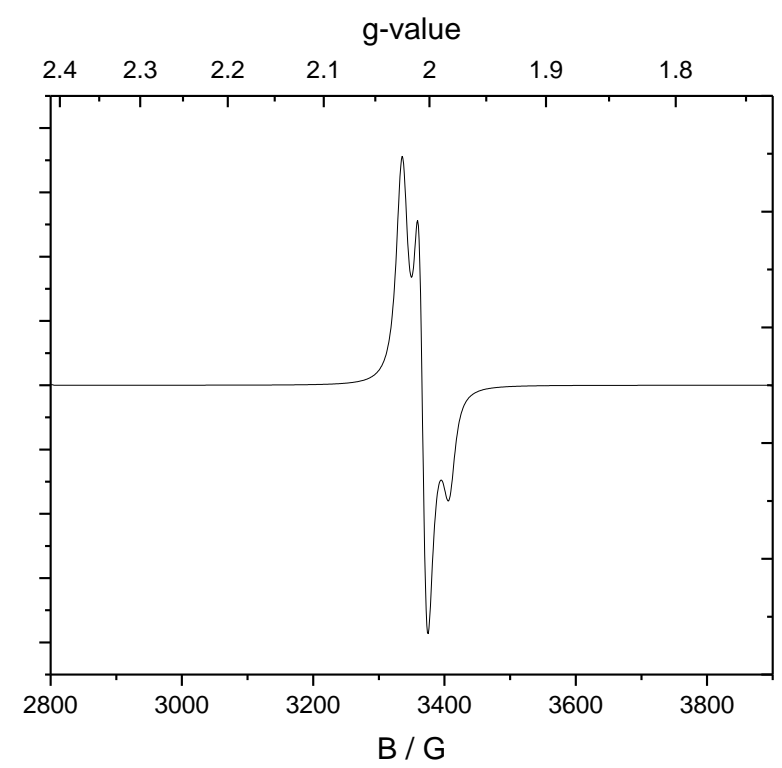

Figure S9: $\quad$ Exemplary EPR spectrum of the solution obtained in course of the reaction of $\mathbf{1 1}^{\mathrm{Cl}}$ with 20 equiv. TEMPO-H.

\subsubsection{Titration experiments}

To study the exchange of $\mathrm{Li}^{+}$by $\mathrm{Zn}^{2+}$ after $\mathrm{O}_{2}$ activation (route 2), a THF solution of $\mathrm{ZnCl}_{2}$ was added to a THF solution of $\left[{ }^{\mathrm{Ph}} \mathrm{L}_{2} \mathrm{Cr}\right] \mathrm{Li}_{2} \mathrm{O}_{2}(\mathrm{THF})_{4}$ (1). A shift of the typical absorption bands of $\mathbf{1}$, the disappearance of the band at $881 \mathrm{~nm}$ was observed leading to the typical spectrum of $\mathbf{1 1}^{\mathbf{C l}}(302,479$ and $675 \mathrm{~nm}$ ) (Figure 4).

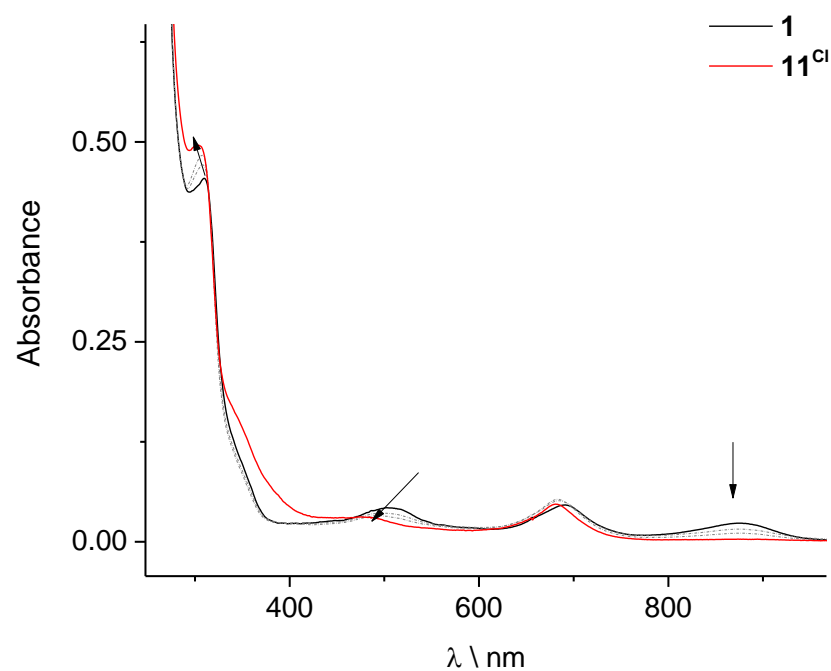

Figure S10. UV/Vis spectra indicating the formation of $\mathbf{1 1}^{\mathrm{Cl}}$ in the reaction of $\mathbf{1}$ with $\mathrm{ZnCl}_{2}$ (route 2). 


\section{Crystal data}

Tab. S1: Crystal data of $9, \mathbf{1 0}^{\mathrm{Cl}}$ and $\mathbf{1 0}^{\mathrm{Br}}$.

\begin{tabular}{|c|c|c|c|}
\hline & 9 & $10^{\mathrm{Cl}}$ & $10^{\mathrm{Br}}$ \\
\hline Empirical formula & $\mathrm{C}_{64} \mathrm{H}_{72} \mathrm{Cl}_{3} \mathrm{Co}_{2} \mathrm{CrO}_{10} \mathrm{Si}_{4}$ & $\mathrm{C}_{60} \mathrm{H}_{64} \mathrm{Cl}_{2} \mathrm{CrO}_{9} \mathrm{Si}_{4} \mathrm{Zn}_{2}$ & $\mathrm{C}_{60} \mathrm{H}_{64} \mathrm{Br}_{2} \mathrm{CrO}_{9} \mathrm{Si}_{4} \mathrm{Zn}_{2}$ \\
\hline Formula weight & 1389.78 & 1295.11 & 1384.03 \\
\hline Crystal system & Monoclinic & Monoclinic & Monoclinic \\
\hline Space group & $P 21 / \mathrm{n}$ & $C 2 / \mathrm{c}$ & $C 2 / \mathrm{c}$ \\
\hline Unit cell dimensions & $\begin{array}{l}a=11.3599(7) \AA, \\
b=24.8528(15) \AA \\
c=22.7115(15) \AA \\
\alpha=90^{\circ} \\
\beta=91.451(3)^{\circ} \\
\gamma=90^{\circ}\end{array}$ & $\begin{array}{l}\mathrm{a}=23.6123(7) \AA \\
\mathrm{b}=11.3799(4) \AA \\
\mathrm{c}=24.4887(9) \AA \\
\alpha=90^{\circ} \\
\beta=108.861(19)^{\circ} \\
\gamma=90^{\circ}\end{array}$ & $\begin{array}{l}a=23.9485(14) \AA \\
b=11.4178(7) \AA \\
c=24.4897(13) \AA \\
\alpha=90^{\circ} \\
\beta=109.296(2)^{\circ} \\
\gamma=90^{\circ}\end{array}$ \\
\hline Volume & $6410.0(7) \AA^{3}$ & $6226.9(8) \AA^{3}$ & $6320.3(6) \AA^{3}$ \\
\hline $\mathrm{Z}$ & 4 & 4 & 4 \\
\hline Density (calculated) & $1.440 \mathrm{Mg} / \mathrm{m}^{3}$ & $1.381 \mathrm{Mg} / \mathrm{m}^{3}$ & $1.455 \mathrm{Mg} / \mathrm{m}^{3}$ \\
\hline $\mathrm{F}(000)$ & 2884 & 2680 & 2824 \\
\hline $\begin{array}{l}\text { Theta range for data } \\
\text { collection }\end{array}$ & 2.430 to $26.453^{\circ}$ & 3.266 to $29.245^{\circ}$ & 2.855 to $25.708^{\circ}$ \\
\hline Reflections collected & 181422 & 25544 & 49151 \\
\hline Independent reflections & $\begin{array}{l}13190[\mathrm{R}(\mathrm{int})= \\
0.1099]\end{array}$ & $8136[\mathrm{R}(\mathrm{int})=0.0401]$ & $5980[\mathrm{R}($ int $)=0.0360]$ \\
\hline $\begin{array}{l}\text { Completeness to theta }= \\
25.000^{\circ}\end{array}$ & $99.9 \%$ & $98.2 \%$ & $99.5 \%\left(\right.$ at $\left.25.242^{\circ}\right)$ \\
\hline Goodness-of-fit on $\mathrm{F}^{2}$ & 1.066 & 0.944 & 1.027 \\
\hline $\mathrm{R}$ indices (all data) & $\begin{array}{l}\mathrm{R} 1=0.0681, \\
\mathrm{wR} 2=0.0872\end{array}$ & $\begin{array}{l}\mathrm{R} 1=0.0449, \\
\mathrm{wR} 2=0.0671\end{array}$ & $\begin{array}{l}\mathrm{R} 1=0.0297, \\
\mathrm{wR} 2=0.0708\end{array}$ \\
\hline
\end{tabular}


A comparison of the bond lengths and angles observed in the siloxide ligand of 9 to the ones observed previously in 6, 7 and 8 revealed an elongation of the $\mathrm{Si}-\mathrm{O}(\mathrm{Cr})$ bond, so that it is similar to the $\mathrm{Si}-\mathrm{O}(\mathrm{H})$ bond length observed in the ligand precursor 1,1,3,3-tetraphenyl-1,3-disilanol (Table S2). In addition to this, a shortening of the neighboring $\mathrm{O}-\mathrm{Si}(\mathrm{O})$ bond was observed. These subtle changes also translate to the angles within 9 leading to a wider OSi-O-SiO angle and a smaller CrO-Si-OSi angle (Supporting Information, Table S2), and they are also reflected in the IR spectra. While the IR spectrum of 9 resembles the spectra of $\mathbf{6 , 7}$ and $\mathbf{8}$ in that it shows bands in the regions between $3070-2850 \mathrm{~cm}^{-1}, 1590$ $1100 \mathrm{~cm}^{-1}, 1050-1030 \mathrm{~cm}^{-1}$ and between $880-860 \mathrm{~cm}^{-1}$ with rather similar patterns and positions $( \pm$ $4 \mathrm{~cm}^{-1}$ ), it differs in a band at $898 \mathrm{~cm}^{-1}$ that for the other complexes occurs at around $970 \mathrm{~cm}^{-1}$ (Figure $\mathrm{S} 1, \mathrm{~S} 2)$. The position of this band of $\mathbf{9}$, which lies in a region typical for $\mathrm{Si}-\mathrm{O}$ stretching frequencies, is, however, very similar to the one observed in the ligand precursor spectrum, consistent with the analogies within the structures. The IR spectrum of $\mathbf{1 0}^{\mathrm{Cl}}$ shows bands identical to the one of $\mathbf{9}$ for the ligand backbone, which nicely meets the expectations based on the structural data determined by X-ray analysis (Table S2). 
Table S2: Bond length and angles determined for complexes with the depicted core structure.

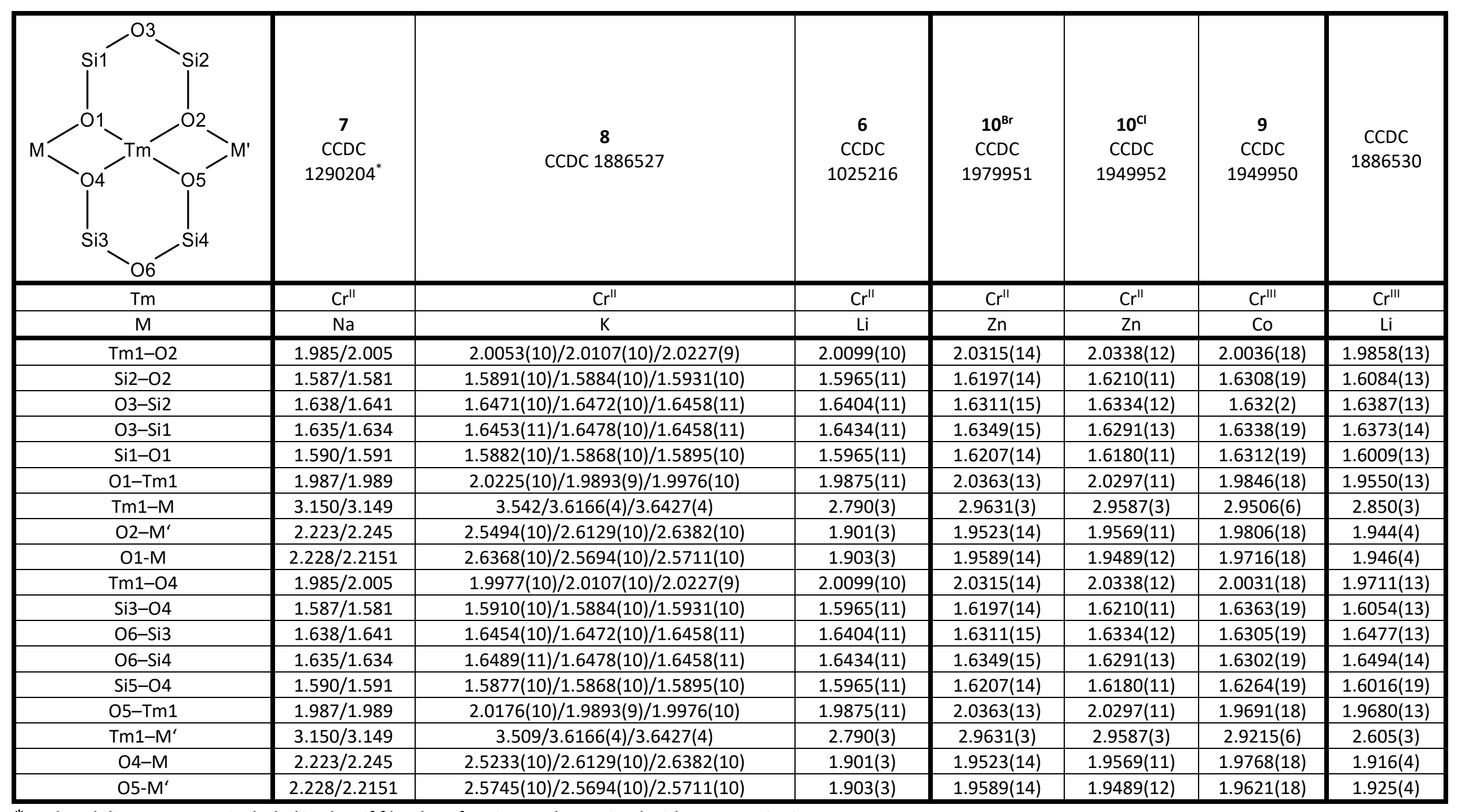

\footnotetext{
* no bond distances were included in the cif file, therefore it was determined with Mercury 3.10
} 


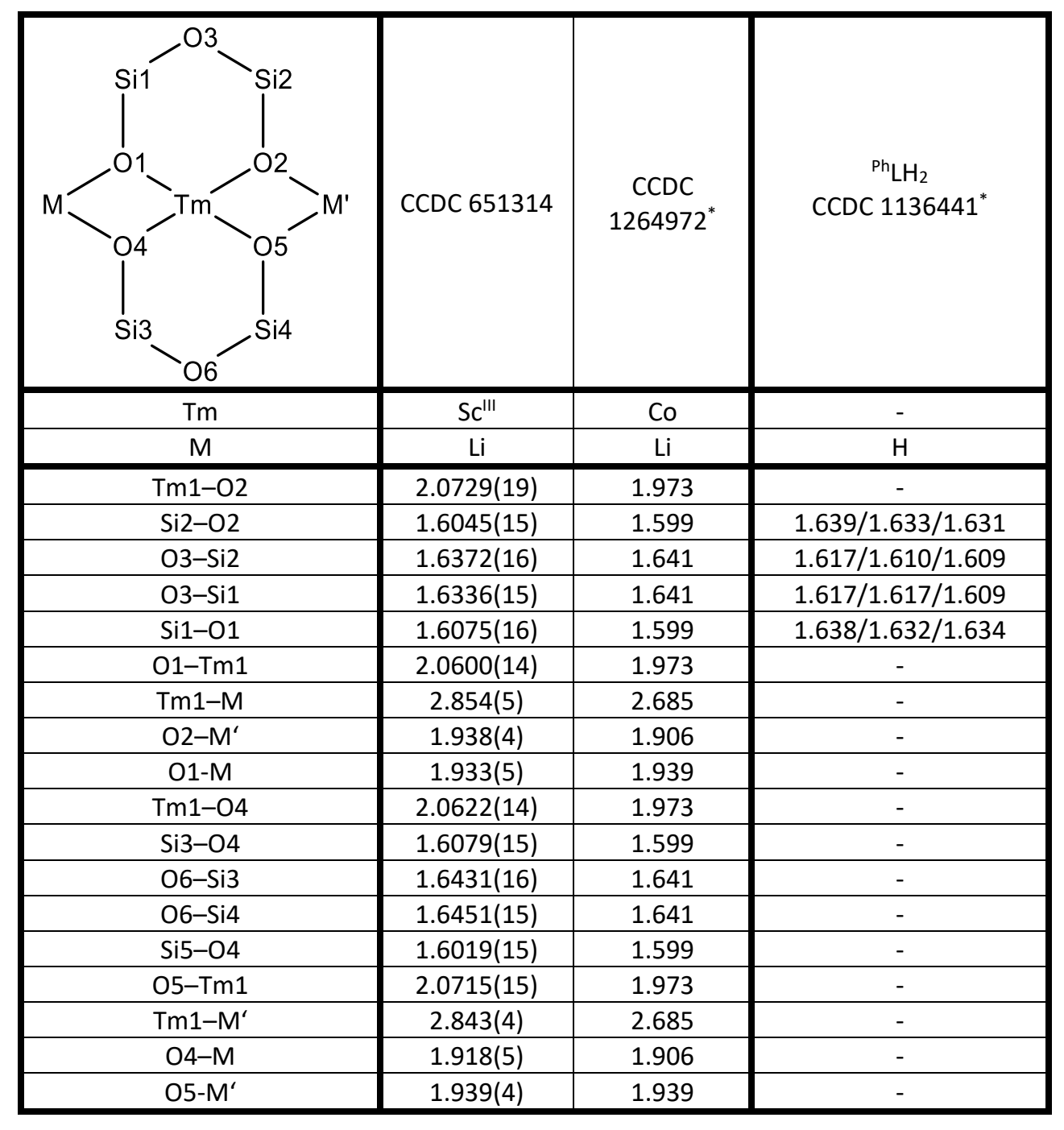




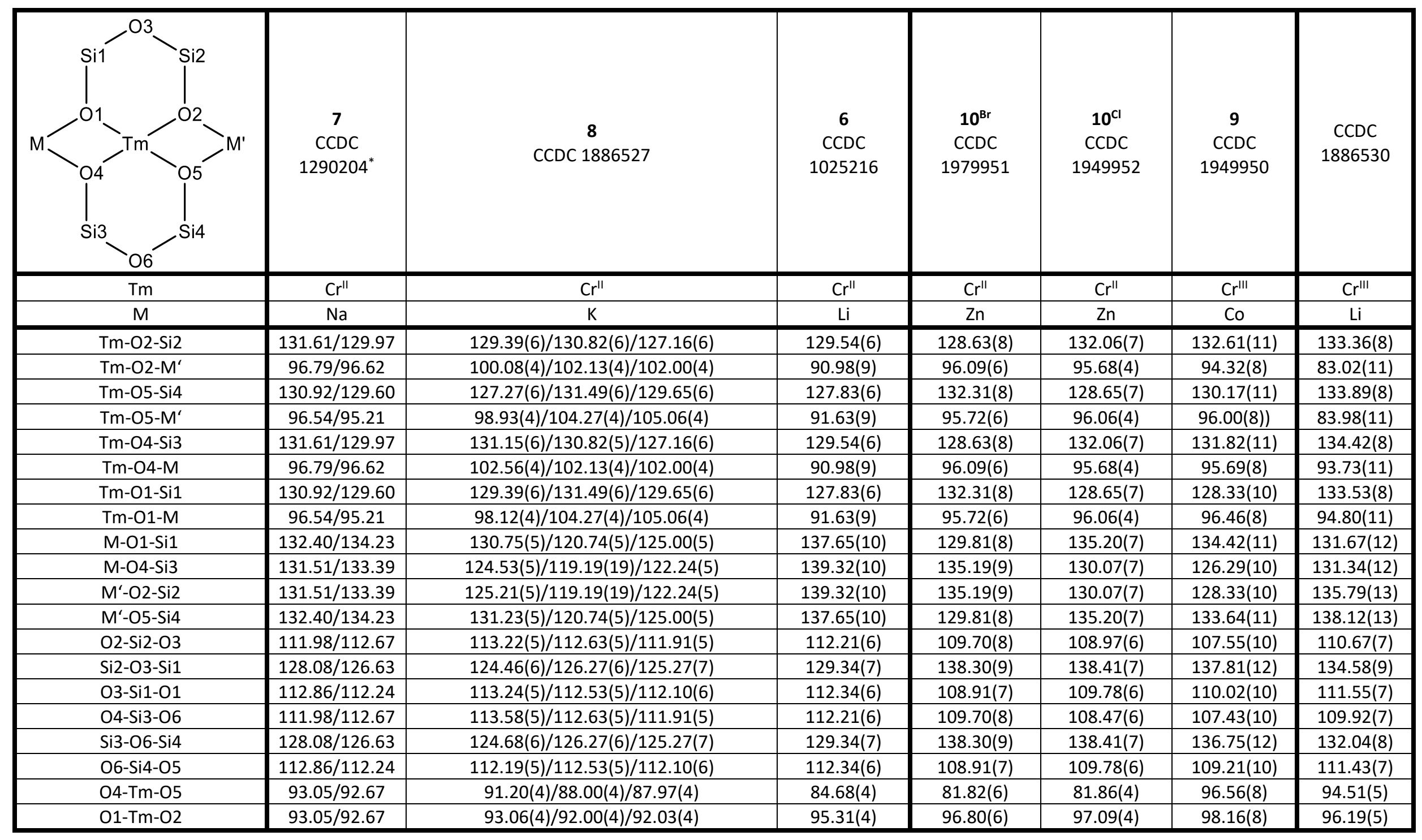




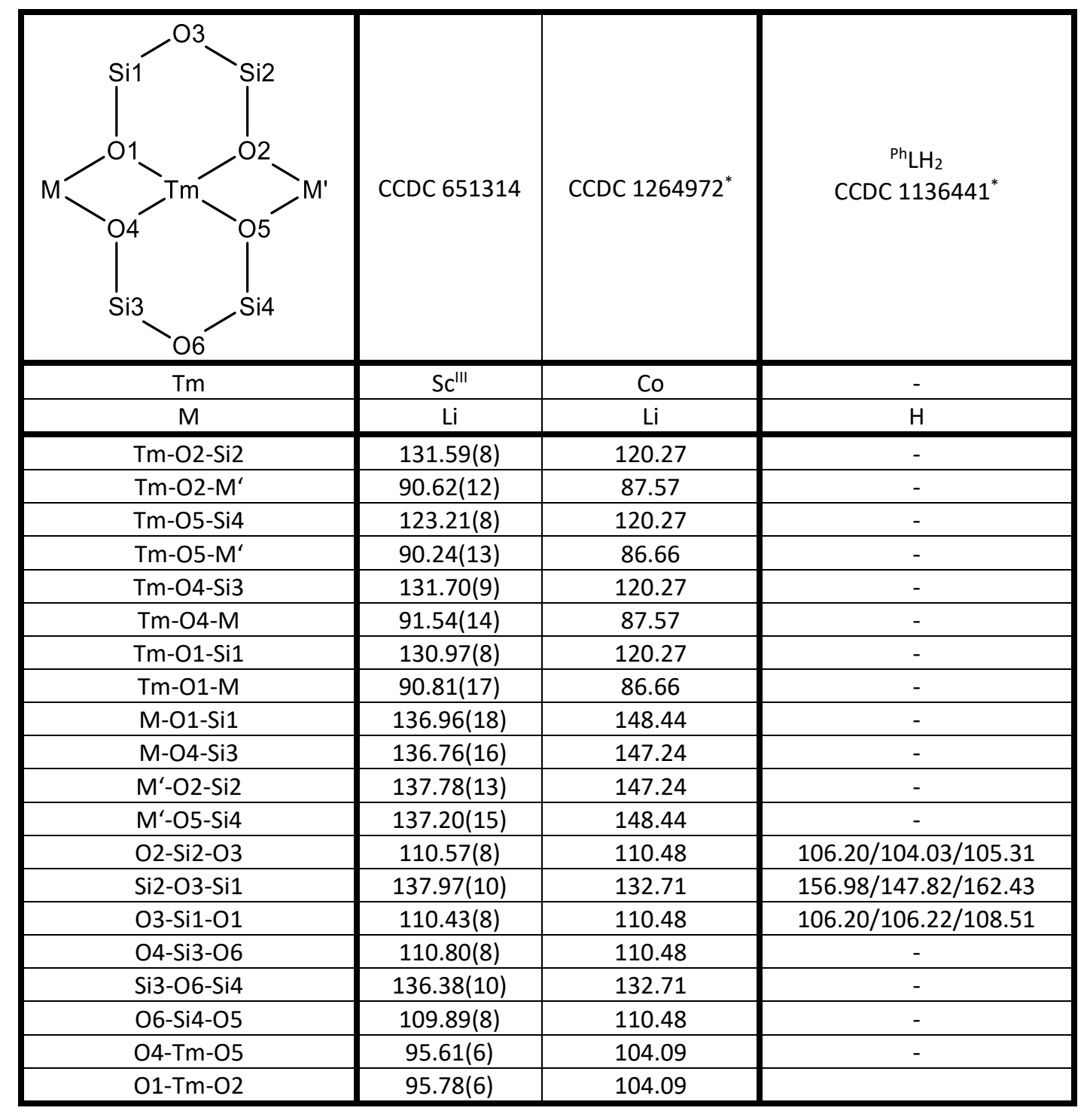




\section{Density functional calculations:}

Geometry optimizations for different spin states were performed in redundant internal coordinates without symmetry restrictions using the Gaussian16 program package. ${ }^{1}$ The molecular structure of $\left[{ }^{\mathrm{Ph}} \mathrm{L}_{2} \mathrm{CrCl}\right][\mathrm{CoCl}]_{2}(\mathrm{THF})_{3}(9)$ as determined by X-ray diffraction analysis was used as starting point. The B3LYP functional ${ }^{2-4}$ was employed amended by the D3 version of Grimme's dispersion, ${ }^{5}$ together with the Def2-SVP basis set, ${ }^{6,7}$ as implemented in Gaussian16. Very tight convergence criteria were chosen for the SCF procedure and a pruned $(99,590)$ "ultrafine" integration grid was used for numerical integrations. Visualization of molecular structures was accomplished with the program Gauss View (Gaussian, Inc.).

\section{$\left[{ }^{\mathrm{Ph}} \mathrm{L}_{2} \mathrm{Cr}\right][\mathrm{CoCl}]_{2} \mathrm{O}_{2}(\mathrm{THF})_{3}$}

Starting with the structure of $\left[{ }^{\mathrm{Ph}} \mathrm{L}_{2} \mathrm{CrCl}\right][\mathrm{CoCl}]_{2}(\mathrm{THF})_{3}(\mathbf{9})$ we removed the $\mathrm{Cl}$ at the $\mathrm{Cr}$ atom and added an $\mathrm{O}_{2}$ unit bridging the $\mathrm{Cr}$ and one $\mathrm{Co}$ atom. Geometry optimizations for different spin states were performed, the relative energies of the resulting molecules are shown in Table S3.

The most favorable state is a quintet state (Figure S11) with three unpaired electrons at each Co atom, one electron at the $\mathrm{O}_{2}$ unit and three antiferromagnetically coupled electrons at the $\mathrm{Cr}$ atom. The $\mathrm{O}-\mathrm{O}$ distance is $1.301 \AA$. These results are consistent with a superoxide complex with two Co(II) ions $\left(\mathrm{d}^{7}\right.$ high spin) and one $\mathrm{Cr}(\mathrm{III})$ ion $\left(\mathrm{d}^{3}\right)$. Moreover, in all spin states there is one unpaired electron delocalised over the atoms of the $\mathrm{O}_{2}$ unit, corresponding to a description as a superoxide.

Tab. S3: Energies and spin densities of optimized structures of $\left[{ }^{\mathrm{Ph}} \mathrm{L}_{2} \mathrm{Cr}\right][\mathrm{CoCl}]_{2} \mathrm{O}_{2}(\mathrm{THF})_{3}$.

\begin{tabular}{|c|c|c|}
\hline spin state & $\begin{array}{c}\text { relative energy } \\
(\mathbf{k J} / \mathbf{m o l})\end{array}$ & Mulliken atomic spin densities ${ }^{\left({ }^{* 1)}\right.}$ \\
\hline triplet $(\mathrm{S}=1)$ & 19.4 & $\mathrm{Co}+2.8, \mathrm{Co}+2.8, \mathrm{Cr}-3.0, \mathrm{O}_{2}-0.9$ \\
\hline quintet $(\mathrm{S}=2)$ & 0 & $\mathrm{Co}+2.8, \mathrm{Co}+2.8, \mathrm{Cr}-3.0, \mathrm{O}_{2}+1.1$ \\
\hline septet $(\mathrm{S}=3)$ & 72.2 & $\mathrm{Co}+2.8, \mathrm{Co}+1.0, \mathrm{Cr}+3.0, \mathrm{O}_{2}-1.0$ \\
\hline nonet $(\mathrm{S}=4)$ & 115.7 & $\mathrm{Co}+2.8, \mathrm{Co}+2.8, \mathrm{Cr}+1.0, \mathrm{O}_{2}+1.0$ \\
\hline undecet $(\mathrm{S}=5)$ & 17.7 & $\mathrm{Co}+2.8, \mathrm{Co}+2.8, \mathrm{Cr}+3.0, \mathrm{O}_{2}+1.0$ \\
\hline
\end{tabular}

${ }^{*}$ Within the $\mathrm{O}_{2}$ unit the spin density is almost equally distributed over the two $\mathrm{O}$ atoms.

If a $\mathrm{Co}$ atom has only 1 unpaired electron, this $\mathrm{Co}$ atom is connected to the $\mathrm{O}_{2}$ unit.

To exclude the possibility of formation of a peroxide $\mathrm{Cr}^{\mathrm{III}}-\mathrm{O}-\mathrm{O}-\mathrm{Co}^{\mathrm{III}}$ the fragment utility of Gaussian was used to allocate a spin density of zero to the $\mathrm{O}_{2}$ unit and an even number of unpaired electrons to the $\mathrm{Co}$ atom connected to $\mathrm{O}_{2}$. All reasonable possibilities of unpaired electron distribution for a $\mathrm{Cr}^{\mathrm{III}}-\mathrm{O}-$ 
$\mathrm{O}-\mathrm{Co}^{\mathrm{III}}$ complex have been tested. However, in all cases the wavefunction converged to systems with one unpaired electron at the $\mathrm{O}_{2}$ unit, i.e. a superoxide.

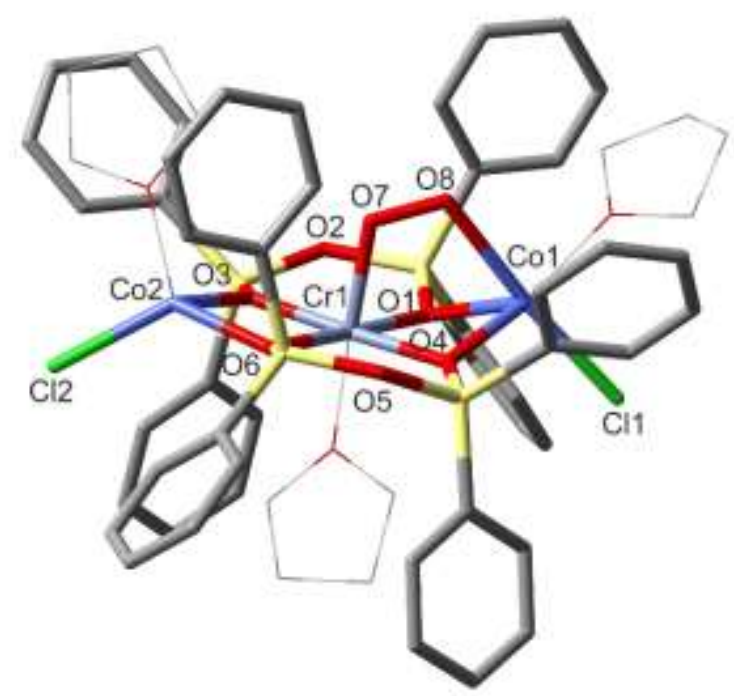

Figure S11: $\quad$ Optimised molecular structure of the quintet ground state of $\left[{ }^{\mathrm{Ph}} \mathrm{L}_{2} \mathrm{Cr}\right][\mathrm{CoCl}]_{2} \mathrm{O}_{2}(\mathrm{THF})_{3}$. Hydrogen atoms are omitted, THF groups shown in grey for clarity.

Cartesian coordinates $(\AA)$ for the theoretical structure of the quintet ground state of $\left[{ }^{\mathrm{Ph}} \mathrm{L}_{2} \mathrm{Cr}\right][\mathrm{CoCl}]_{2} \mathrm{O}_{2}(\mathrm{THF})_{3}$ :

B3LYP/Def2-SVP, Quintet state, E = -9038.62257108 hartree

\begin{tabular}{lrcc} 
& $\mathbf{x}$ & $\mathbf{y}$ & $\mathbf{z}$ \\
\hline $\mathrm{Cr}$ & 0.080446 & 0.036946 & 0.289184 \\
$\mathrm{Co}$ & -2.751765 & -0.608948 & -0.199016 \\
$\mathrm{Co}$ & 2.964730 & 0.621192 & -0.263541 \\
$\mathrm{Si}$ & -2.042192 & 2.582332 & 0.006998 \\
$\mathrm{Si}$ & 0.940388 & 3.219241 & 0.221425 \\
$\mathrm{Si}$ & -0.748818 & -3.137794 & 0.640457 \\
$\mathrm{Si}$ & 2.143433 & -2.543289 & -0.202317 \\
$\mathrm{Cl}$ & -4.277573 & -0.918075 & 1.486190 \\
$\mathrm{Cl}$ & 4.858657 & 1.152633 & 0.818601 \\
$\mathrm{O}$ & -1.620002 & 1.023655 & 0.382982 \\
$\mathrm{O}$ & -0.653718 & 3.493206 & -0.168542 \\
$\mathrm{O}$ & 1.273622 & 1.599361 & 0.027025 \\
$\mathrm{O}$ & -1.077073 & -1.523799 & 0.472910 \\
$\mathrm{O}$ & 0.765656 & -3.445664 & 0.014187 \\
$\mathrm{O}$ & 1.827353 & -0.952339 & 0.179567 \\
$\mathrm{O}$ & -4.041904 & -1.099228 & -1.726560 \\
$\mathrm{O}$ & 0.296918 & 0.181088 & 2.316514 \\
$\mathrm{O}$ & 3.389973 & 0.825688 & -2.215321 \\
$\mathrm{O}$ & -0.178848 & -0.114067 & -1.629374
\end{tabular}




\begin{tabular}{|c|c|c|c|}
\hline $\mathrm{O}$ & -1.397686 & -0.411611 & -1.974161 \\
\hline $\mathrm{C}$ & -3.082051 & 3.347092 & 1.359374 \\
\hline $\mathrm{C}$ & -3.222288 & 4.747673 & 1.431204 \\
\hline $\mathrm{C}$ & -3.967424 & 5.344179 & 2.451391 \\
\hline $\mathrm{C}$ & -4.591150 & 4.545624 & 3.417652 \\
\hline $\mathrm{C}$ & -4.469798 & 3.154450 & 3.354364 \\
\hline $\mathrm{C}$ & -3.720327 & 2.558408 & 2.333813 \\
\hline $\mathrm{C}$ & -2.956908 & 2.538662 & -1.630242 \\
\hline $\mathrm{C}$ & -4.362989 & 2.529070 & -1.668703 \\
\hline $\mathrm{C}$ & -5.049538 & 2.382221 & -2.878974 \\
\hline $\mathrm{C}$ & -4.335676 & 2.239082 & -4.072876 \\
\hline $\mathrm{C}$ & -2.935857 & 2.248166 & -4.053019 \\
\hline $\mathrm{C}$ & -2.255173 & 2.397140 & -2.842466 \\
\hline $\mathrm{C}$ & 1.237387 & 3.662453 & 2.017484 \\
\hline $\mathrm{C}$ & 0.219304 & 4.228763 & 2.807058 \\
\hline $\mathrm{C}$ & 0.425363 & 4.501350 & 4.163811 \\
\hline $\mathrm{C}$ & 1.661250 & 4.221486 & 4.754021 \\
\hline $\mathrm{C}$ & 2.686588 & 3.661342 & 3.982984 \\
\hline $\mathrm{C}$ & 2.474807 & 3.379007 & 2.630718 \\
\hline $\mathrm{C}$ & 1.978917 & 4.137571 & -1.040749 \\
\hline $\mathrm{C}$ & 3.385981 & 4.064516 & -1.032876 \\
\hline $\mathrm{C}$ & 4.140173 & 4.659957 & -2.048040 \\
\hline $\mathrm{C}$ & 3.501617 & 5.338131 & -3.092660 \\
\hline $\mathrm{C}$ & 2.105504 & 5.421696 & -3.114864 \\
\hline $\mathrm{C}$ & 1.352691 & 4.827672 & -2.096248 \\
\hline $\mathrm{C}$ & -0.752219 & -3.550847 & 2.464942 \\
\hline $\mathrm{C}$ & 0.382274 & -4.101258 & 3.090027 \\
\hline $\mathrm{C}$ & 0.396117 & -4.346718 & 4.467569 \\
\hline $\mathrm{C}$ & -0.731797 & -4.055601 & 5.240864 \\
\hline $\mathrm{C}$ & -1.868118 & -3.507010 & 4.634344 \\
\hline $\mathrm{C}$ & -1.875792 & -3.247776 & 3.260970 \\
\hline $\mathrm{C}$ & -1.967057 & -4.079168 & -0.432809 \\
\hline $\mathrm{C}$ & -1.504978 & -4.780016 & -1.563393 \\
\hline $\mathrm{C}$ & -2.397336 & -5.430264 & -2.422507 \\
\hline $\mathrm{C}$ & -3.770871 & -5.395009 & -2.161119 \\
\hline $\mathrm{C}$ & -4.247179 & -4.699705 & -1.044254 \\
\hline $\mathrm{C}$ & -3.354834 & -4.045782 & -0.190049 \\
\hline $\mathrm{C}$ & 3.466405 & -3.216898 & 0.933908 \\
\hline $\mathrm{C}$ & 4.276613 & -2.369710 & 1.711246 \\
\hline $\mathrm{C}$ & 5.232680 & -2.896701 & 2.586031 \\
\hline $\mathrm{C}$ & 5.390325 & -4.280756 & 2.701021 \\
\hline $\mathrm{C}$ & 4.592516 & -5.139005 & 1.934757 \\
\hline $\mathrm{C}$ & 3.640937 & -4.609894 & 1.059204 \\
\hline $\mathrm{C}$ & 2.629049 & -2.633303 & -2.011399 \\
\hline $\mathrm{C}$ & 3.968313 & -2.799524 & -2.406704 \\
\hline $\mathrm{C}$ & 4.324220 & -2.816182 & -3.760470 \\
\hline $\mathrm{C}$ & 3.339541 & -2.667363 & -4.741780 \\
\hline $\mathrm{C}$ & 2.000860 & -2.499239 & -4.365649 \\
\hline
\end{tabular}




\begin{tabular}{|c|c|c|c|}
\hline C & 1.649523 & -2.482624 & -3.013475 \\
\hline C & -3.673815 & -1.653732 & -3.018563 \\
\hline C & -4.988085 & -2.135311 & -3.626643 \\
\hline C & -6.017041 & -1.191354 & -2.990323 \\
\hline $\mathrm{C}$ & -5.479967 & -1.038394 & -1.573929 \\
\hline $\mathrm{C}$ & -0.844591 & 0.340374 & 3.207033 \\
\hline $\mathrm{C}$ & -0.318849 & -0.103066 & 4.566346 \\
\hline $\mathrm{C}$ & 1.165509 & 0.278077 & 4.489555 \\
\hline $\mathrm{C}$ & 1.515367 & -0.088031 & 3.053999 \\
\hline $\mathrm{C}$ & 2.385336 & 1.190660 & -3.203357 \\
\hline $\mathrm{C}$ & 3.134750 & 1.146313 & -4.528063 \\
\hline $\mathrm{C}$ & 4.554713 & 1.566289 & -4.119322 \\
\hline $\mathrm{C}$ & 4.728404 & 0.875398 & -2.770527 \\
\hline $\mathrm{H}$ & -2.728530 & 5.382608 & 0.688971 \\
\hline $\mathrm{H}$ & -4.060710 & 6.432714 & 2.496221 \\
\hline $\mathrm{H}$ & -5.173887 & 5.010360 & 4.217843 \\
\hline $\mathrm{H}$ & -4.961011 & 2.525372 & 4.101642 \\
\hline $\mathrm{H}$ & -3.644238 & 1.469834 & 2.290227 \\
\hline $\mathrm{H}$ & -4.930539 & 2.638942 & -0.739356 \\
\hline $\mathrm{H}$ & -6.142926 & 2.382015 & -2.890412 \\
\hline $\mathrm{H}$ & -4.869550 & 2.124223 & -5.020353 \\
\hline $\mathrm{H}$ & -2.374936 & 2.135996 & -4.984855 \\
\hline $\mathrm{H}$ & -1.162070 & 2.388932 & -2.836376 \\
\hline $\mathrm{H}$ & -0.752415 & 4.453913 & 2.365252 \\
\hline $\mathrm{H}$ & -0.384496 & 4.933495 & 4.757707 \\
\hline $\mathrm{H}$ & 1.825640 & 4.435744 & 5.813622 \\
\hline $\mathrm{H}$ & 3.653852 & 3.431741 & 4.437936 \\
\hline $\mathrm{H}$ & 3.285019 & 2.913868 & 2.063130 \\
\hline $\mathrm{H}$ & 3.911847 & 3.518109 & -0.245129 \\
\hline $\mathrm{H}$ & 5.231119 & 4.590439 & -2.023927 \\
\hline $\mathrm{H}$ & 4.091997 & 5.802925 & -3.887108 \\
\hline $\mathrm{H}$ & 1.601526 & 5.951666 & -3.927779 \\
\hline $\mathrm{H}$ & 0.261288 & 4.887717 & -2.122125 \\
\hline $\mathrm{H}$ & 1.271105 & -4.332715 & 2.498558 \\
\hline $\mathrm{H}$ & 1.290631 & -4.767087 & 4.935187 \\
\hline $\mathrm{H}$ & -0.724503 & -4.250084 & 6.316913 \\
\hline $\mathrm{H}$ & -2.748025 & -3.265116 & 5.236547 \\
\hline $\mathrm{H}$ & -2.757089 & -2.776435 & 2.815939 \\
\hline $\mathrm{H}$ & -0.432492 & -4.809763 & -1.772976 \\
\hline $\mathrm{H}$ & -2.019319 & -5.968580 & -3.296005 \\
\hline $\mathrm{H}$ & -4.469629 & -5.907261 & -2.828367 \\
\hline $\mathrm{H}$ & -5.320363 & -4.662061 & -0.837883 \\
\hline $\mathrm{H}$ & -3.755316 & -3.480686 & 0.655460 \\
\hline $\mathrm{H}$ & 4.170966 & -1.286255 & 1.634172 \\
\hline $\mathrm{H}$ & 5.854390 & -2.219356 & 3.177407 \\
\hline $\mathrm{H}$ & 6.134940 & -4.693399 & 3.387262 \\
\hline $\mathrm{H}$ & 4.711245 & -6.222309 & 2.023470 \\
\hline $\mathrm{H}$ & 3.014413 & -5.291218 & 0.475370 \\
\hline
\end{tabular}




\begin{tabular}{lrrr}
$\mathrm{H}$ & 4.745854 & -2.922249 & -1.646327 \\
$\mathrm{H}$ & 5.370082 & -2.951673 & -4.049390 \\
$\mathrm{H}$ & 3.613273 & -2.684888 & -5.800306 \\
$\mathrm{H}$ & 1.228289 & -2.380994 & -5.130316 \\
$\mathrm{H}$ & 0.602091 & -2.341261 & -2.736067 \\
$\mathrm{H}$ & -2.942062 & -2.454607 & -2.845000 \\
$\mathrm{H}$ & -3.200229 & -0.851114 & -3.601350 \\
$\mathrm{H}$ & -4.975318 & -2.088678 & -4.725580 \\
$\mathrm{H}$ & -5.183647 & -3.176435 & -3.328885 \\
$\mathrm{H}$ & -7.043211 & -1.587249 & -3.006372 \\
$\mathrm{H}$ & -6.010545 & -0.216246 & -3.501715 \\
$\mathrm{H}$ & -5.725219 & -0.083865 & -1.090742 \\
$\mathrm{H}$ & -5.791527 & -1.855718 & -0.904970 \\
$\mathrm{H}$ & -1.672689 & -0.263612 & 2.813826 \\
$\mathrm{H}$ & -1.131878 & 1.402848 & 3.190043 \\
$\mathrm{H}$ & -0.432460 & -1.191509 & 4.679608 \\
$\mathrm{H}$ & -0.853374 & 0.388625 & 5.392297 \\
$\mathrm{H}$ & 1.793227 & -0.260239 & 5.214713 \\
$\mathrm{H}$ & 1.299854 & 1.359677 & 4.644171 \\
$\mathrm{H}$ & 2.323650 & 0.515920 & 2.619193 \\
$\mathrm{H}$ & 1.762608 & -1.155140 & 2.939628 \\
$\mathrm{H}$ & 2.025509 & 2.201198 & -2.957271 \\
$\mathrm{H}$ & 1.557187 & 0.476869 & -3.113588 \\
$\mathrm{H}$ & 2.685983 & 1.814906 & -5.277092 \\
$\mathrm{H}$ & 3.134881 & 0.120419 & -4.926999 \\
$\mathrm{H}$ & 4.605686 & 2.658889 & -3.994299 \\
$\mathrm{H}$ & 5.324291 & 1.260083 & -4.842988 \\
$\mathrm{H}$ & 5.086132 & -0.161562 & -2.873301 \\
$\mathrm{H}$ & 5.364792 & 1.411841 & -2.053443 \\
\hline & & &
\end{tabular}

\section{References:}

1. M. J. Frisch, G. W. T., H. B. Schlegel, G. E. Scuseria, M. A. Robb, J. R. Cheeseman, G. Scalmani, V. Barone, B. Mennucci, G. A. Petersson, H. Nakatsuji, M. Caricato, X. Li, H. P. Hratchian, A. F. Izmaylov, J. Bloino, G. Zheng, J. L. Sonnenberg, M. Hada, M. Ehara, K. Toyota, R. Fukuda, J. Hasegawa, M. Ishida, T. Nakajima, Y. Honda, O. Kitao, H. Nakai, T. Vreven, J. A. Montgomery, Jr., J. E. Peralta, F. Ogliaro, M. Bearpark, J. J. Heyd, E. Brothers, K. N. Kudin, V. N. Staroverov, R. Kobayashi, J. Normand, K. Raghavachari, A. Rendell, J. C. Burant, S. S. Iyengar, J. Tomasi, M. Cossi, N. Rega, J. M. Millam, M. Klene, J. E. Knox, J. B. Cross, V. Bakken, C. Adamo, J. Jaramillo, R. Gomperts, R. E. Stratmann, O. Yazyev, A. J. Austin, R. Cammi, C. Pomelli, J. W. Ochterski, R. L. Martin, K. Morokuma, V. G. Zakrzewski, G. A. Voth, P. Salvador, J. J. Dannenberg, S. Dapprich, A. D. Daniels, Ö. Farkas, J. B. Foresman, J. V. Ortiz, J. Cioslowski, and D. J. Fox. Gaussian09 Revision D01. Gaussian, Inc., Wallingford CT 2009. 
2. Becke, A. D. Density-functional exchange-energy approximation with correct asymptotic behavior. Phys. Rev. A 1988, 38 (6), 3098-3100 DOI: 10.1103/PhysRevA.38.3098.

3. Becke, A. D. Density-functional thermochemistry. III. The role of exact exchange. J. Chem. Phys. 1993, 98 (7), 5648-5652 DOI: 10.1063/1.464913.

4. Lee, C.; Yang, W.; Parr, R. G. Development of the Colle-Salvetti correlation-energy formula into a functional of the electron density. Phys. Rev.B 1988, 37 (2), 785-789 DOI: 10.1103/PhysRevB.37.785.

5. Grimme, S.; Ehrlich, S.; Goerigk, L. Effect of the damping function in dispersion corrected density functional theory. J. Comput. Chem. 2011, 32 (7), 1456-1465 DOI: 10.1002/jcc.21759.

6. Weigend, F.; Ahlrichs, R. Balanced basis sets of split valence, triple zeta valence and quadruple zeta valence quality for $\mathrm{H}$ to $\mathrm{Rn}$ : Design and assessment of accuracy. Phys. Chem. Chem. Phys. 2005, 7 (18), 3297-3305 DOI: 10.1039/B508541A.

7. Weigend, F. Accurate Coulomb-fitting basis sets for H to Rn. Phys. Chem. Chem. Phys. 2006, 8 (9), 1057-1065 DOI: 10.1039/B515623H. 